\title{
SABER HISTÓRICO E DESENVOLVIMENTO DAS COMPETÊNCIAS DE LEITURA E ESCRITA NO CURRÍCULO OFICIAL DO ESTADO DE SÃO PAULO
}

\author{
Historical Knowledge and Development of Reading and \\ Writing Skills in the Official Curriculum of the \\ State of São Paulo, Brazil
}

Jorge Eschriqui Vieira Pinto ${ }^{1}$

\begin{abstract}
RESUMO
O saber histórico de sala de aula pode se tornar uma importante ferramenta para a formação cidadã dos alunos na medida em que relaciona os problemas, os desafios, as demandas e a participação dos diversos atores sociais no cenário sócio-político contemporẩneo às identidades, negociações, lutas e conquistas dos vários segmentos sociais que contribuíram no passado para a formação da sociedade nacional. Isso demanda práticas pedagógicas que superem o ensino tradicional da disciplina de História baseado na transmissão de conteúdos prontos e acabados e na memorização de datas, fatos e personagens, tornando-se os alunos em sujeitos ativos do processo de ensino e aprendizagem, capazes de refletirem criticamente sobre os conteúdos abordados em sala e os relacionar com a realidade vivida por eles. A base dessa reflexão é a capacidade argumentativa, que depende fundamentalmente do estímulo ao desenvolvimento das competências de leitura e escrita. O objetivo deste artigo é analisar como o Currículo Oficial do Estado de São Paulo articula a aquisição dessas competências com o aprendizado dos conteúdos trabalhados pela História a partir do $6^{\circ}$ ano do ensino fundamental.
\end{abstract}

Palavras-Chave: Saber Histórico, Leitura, Escrita, Currículo.

1 Doutor em História pela Universidade Estadual Paulista (UNESP). Pesquisador - Pós-graduação - Faculdade UnyLeya e escritor pela Thesaurus Editora (Brasília-DF). E-mail: jschriqui@ yahoo.com.br. ORCID: http://orcid.org/0000-0001-5359-6264. 
PINTO, J. E. V. Saber Histórico e Desenvolvimento das Competências de Leitura e Escrita...

\begin{abstract}
The classroom historical knowledge can become an important tool for the formation of the students'citizens insofar as it relates the problems, challenges, demands and participation of the various social actors in the contemporary socio-political scenario to identities, negotiations, struggles and achievements of the various social segments that contributed in the past to the formation of national society. This demands pedagogical practices that overcome the traditional teaching of the History discipline based on the transmission of ready and finished contents and the memorization of dates, facts and characters. As a consequence, transforming the students in active subjects of the teaching and learning process, in addition to making them able to reflect critically about the contents covered in the room and relate them to the reality lived by them. The basis of this reflection is the argumentative capacity, which depends fundamentally on stimulating the development of reading and writing skills. The objective of this article is to analyze how the Official Curriculum of the State of São Paulo, Brazil, articulates the acquisition of these competences with the learning of the contents worked in History from the 6th year of elementary school.
\end{abstract}

Keywords: Historical Knowledge, Reading, Writing, Curriculum.

Em nossa época, mais do que nunca exposta às toxinas da mentira $\mathrm{e}$ do falso rumor, que escândalo o método crítico não figurar nem no menor cantinho dos programas de ensino! Pois ele deixou de ser apenas o humilde auxiliar de alguns trabalhos de oficina. Doravante vê abrirem-se diante de si horizontes bem mais vastos: e a História tem o direito de contar entre as suas glórias mais seguras ter assim, ao elaborar sua técnica, aberto aos homens um novo caminho rumo à verdade e, por conseguinte, àquilo que é justo (BLOCH, 2001, p.124).

A década de 1990 foi marcada pela adoção por parte dos governos brasileiros, de uma política neoliberal responsável por uma ampla abertura da economia brasileira para o mercado internacional por meio da supressão de um excessivo protecionismo que impedia uma maior entrada de capitais externos e a concorrência de empresas e produtos estrangeiros com a produção nacional, da privatização de empresas estatais sob o argumento da necessidade de se reduzir o aparelho estatal para a sua maior eficiência de ação e investimentos em áreas de real interesse social, como educação, saúde e segurança pública, da concessão à iniciativa privada de direitos de exploração de serviços em diversos setores da economia nacional, da participação do país no contexto internacional por meio de seu ingresso em 
blocos regionais de integração econômica (como é o caso do Mercado Comum do Cone Sul - MERCOSUL) e da realização de um conjunto de reformas estruturais pelo Estado, contando com o apoio de organismos internacionais, como o Banco Mundial e o Banco Interamericano de Desenvolvimento, para a inserção do país na nova economia globalizada. Entre essas reformas, pode-se citar a reforma educacional, iniciada durante o Governo de Fernando Henrique Cardoso (1995-2002), cujas maiores expressões são a Lei de Diretrizes e Bases da Educação Nacional - LDBEN (Lei $n^{\circ}$ 9.394/96) e, a partir de 1997, os Parâmetros Curriculares Nacionais (PCN), e continuada mesmo com a mudança para governos de esquerda no ano de 2003, como se comprova por meio de documentos como as Diretrizes Curriculares Nacionais (2010), o Plano Nacional de Educação (2014) e a Base Nacional Comum Curricular, que teve o processo de discussões e de consulta popular sobre a sua elaboração iniciado em setembro de 2015, ainda durante o período de Dilma Rousseff na Presidência da República (20112016), e seria homologada apenas em dezembro de 2017 no mandato presidencial do Michel Temer (2016-2018). Segundo Elizabeth Carvalho,

a discussão sobre a necessidade de base nacional comum curricular no Brasil não é recente. Segundo a linha do tempo elaborada pelo próprio Ministério da Educação (MEC), o debate atual teria se iniciado com a Constituição de 1988, seguindo com a LDB, a elaboração de Parâmetros Curriculares Nacionais e culminando com a promulgação das Diretrizes Curriculares Nacionais Gerais para a Educação Básica e do Plano Nacional de Educação (PNE) (MACEDO, 2015, p.892).

O conjunto de ações estatais que constituem a ampla reforma educacional realizada desde a década de 1990, incluindo a Base Nacional Comum Curricular, tem as suas origens na participação do Brasil entre os países signatários da carta de propostas para o estabelecimento de necessidades básicas e metas de aprendizagem para a universalização do acesso à educação fundamental, elaborada durante a Conferência Mundial sobre Educação para Todos, realizada em Jomtien, na Tailândia, em 1990. A partir dessa conferência internacional convocada pela Organização das Nações Unidas para a Educação, a Ciência e a Cultura (UNESCO), pelo 
PINTO, J. E. V. Saber Histórico e Desenvolvimento das Competências de Leitura e Escrita...

Fundo das Nações Unidas para a Infância (UNICEF), pelo Banco Mundial e pelo Programa das Nações Unidas para o Desenvolvimento (PNUD), o Estado brasileiro comprometeu-se a adequar o sistema educacional brasileiro às expectativas de organismos internacionais atuantes na ordem política e econômica mundial quanto a uma educação forjada nos princípios da universalidade e qualidade para atender às demandas da economia globalizada e às exigências do mercado de trabalho. Baseando-se nessa constatação, pode-se falar que o conjunto de iniciativas públicas no âmbito da educação adotado por diferentes governos em consonância com a carta de propostas da Conferência Mundial sobre Educação para Todos e as demandas de organismos internacionais por ampliação no acesso e melhoria na qualidade da Educação Básica apenas comprovam que a reforma educacional no Brasil, iniciada nos anos 1990, demonstra ser uma política de Estado e não de um governo com tendência política à direita, à esquerda ou ao centro.

As pressões e o financiamento das reformas educacionais por parte de organismos financeiros internacionais na década de 1990, sobretudo do Banco Mundial e do Banco Interamericano de Desenvolvimento (BID), surtiram efeito para que o Brasil acompanhasse uma tendência global à homogeneização curricular e à implantação de sistemas de avaliação externa para a medição da qualidade do ensino e o estabelecimento de metas de desempenho escolar. Dessa forma, o país uniu-se a outros em escala global, a partir dessa época, como, por exemplo, Uruguai, Argentina, Paraguai, Portugal, Espanha, etc., comprometendo-se a realizar uma reforma educacional de cunho neoliberal que atendesse às expectativas da nova ordem econômica mundial, à lógica do pensamento neoliberal e às novas exigências de qualificação profissional impostas pelo mercado de trabalho em escala mundial. Ademais, em 1992, ficou estabelecido no âmbito do Mercosul que os membros do bloco de integração econômica regional na época (Argentina, Brasil, Paraguai e Uruguai) iniciariam um processo de harmonização e compatibilização dos sistemas educacionais dos quatro países por meio da criação de bases curriculares nacionais, o que pode ser observado com a elaboração dos Contenidos Basicos Comunes para la Educación Basica (Argentina-1995), dos Parâmetros Curriculares Nacionais (Brasil-1997), dos Programas del Estudio (Paraguai-1995) e do Plan Piloto - Currículo Experimental (Uruguai-1995). Portanto, 


\begin{abstract}
vivia-se, em meados da década de 1990, o auge da definição de políticas educacionais nacionais marcadas por intervenções centralizadas no currículo, na avaliação e na formação dos professores. Segundo Ball, este era o tripé característico das reformas de cunho neoliberal dos anos 1990. Tais reformas, embora com características muito diversas em função da história dos diferentes países, surgiam na Europa, nos Estados Unidos e também na América Latina, aí seguindo políticas propostas pelo Banco Mundial. No Brasil, além dos parâmetros curriculares nacionais, em 1997, foram construídas matrizes de referência para a avaliação iniciada no começo da década (MACEDO, 2014, p.1533).
\end{abstract}

A repercussão do pensamento e do modus operandi dos organismos financeiros internacionais na reforma educacional brasileira explica, em boa parte, a aplicação pelos órgãos públicos responsáveis pela gestão das redes federal, estaduais e municipais de ensino de certos conceitos e metodologias específicos de algumas áreas das Ciências Sociais Aplicadas (sobretudo da Economia e Administração), como planejamento, avaliação sistêmica, plano de metas e resultados, índices de desempenho e de qualidade, competências/habilidades, gestão de recursos, etc. Tais terminologias e métodos estão presentes até o momento atual em programas curriculares e outros tipos de documentos educacionais, como é o caso do Currículo do Estado de São Paulo: Ciências Humanas e suas tecnologias. Trata-se da transposição da mentalidade, lógica de funcionamento e linguagem da economia e do mercado para a gestão e a ciência da Educação. Desse modo, segundo Kátia Abud, "o discurso do poder pronuncia-se sobre a educação e define seu sentido, forma, finalidade e conteúdo e estabelece, sobre cada disciplina, o controle da informação a ser transmitida e da formação pretendida. Assim, a burocracia estatal legisla, regulamenta e controla o trabalho pedagógico (CHAUÍ)" (ABUD, 2006, p.28).

Ademais, não é por acaso que se observa também nos documentos oficiais uma preocupação constante em se articular o aprendizado dos conhecimentos abordados ao longo dos conteúdos das várias disciplinas da grade curricular com a aquisição de competências e habilidades a cada etapa da vida escolar, entre as quais se pode citar as competências leitora e escritora. $\mathrm{O}$ objetivo dessa proposta pedagógica é transformar os 
PINTO, J. E. V. Saber Histórico e Desenvolvimento das Competências de Leitura e Escrita...

conhecimentos adquiridos no meio escolar em saberes que serão mobilizados pelo aluno ao longo de sua vida para a percepção e a reflexão crítica da realidade na qual está inserido e essenciais para a sua capacitação e o seu futuro ingresso no mercado de trabalho. Mas, afinal, qual é a diferença conceitual entre conhecimentos e saberes escolares?

Entre as possíveis definições de saber, pode-se conceituá-lo como o conhecimento presente na mente humana sobre uma questão, um problema ou certa ciência, que, uma vez resgatado pelo indivíduo em certas circunstâncias da vida, possibilita-lhe uma representação da realidade objetiva e, consequentemente, uma tomada de decisões consciente para a intervenção no meio. Em outras palavras, o conhecimento só se torna saber quando é internalizado de forma definitiva na mente do indivíduo, transformando-se em referencial cognitivo que é mobilizado, de acordo com as circunstâncias, para a compreensão e atuação na realidade.

Como o indivíduo mantém consigo por toda a existência aquelas aprendizagens que possam ser utilizadas continuamente para o seu entendimento do mundo e a sua sobrevivência no meio, não há como se desvincular qualquer saber adquirido na escola do contexto social, econômico e cultural no qual está inserido cotidianamente. Nesse sentido, de acordo com o Currículo do Estado de São Paulo: Ciências Humanas e suas tecnologias,

a formação dos cidadãos ultrapassa as aulas de História e a própria escola, em seu conjunto, já que as bases dessa formação são constituídas nos ambientes sociais que os alunos frequentam, principalmente os familiares. Por isso, é necessário compartilhar essa realidade com a formação específica da disciplina, que devem animar o trabalho de todo educador, e não apenas do de História.

Desse modo, será possível auxiliar o educando a ter um entendimento mais adequado de sua realidade social a partir da transformação de suas experiências vividas em experiências compreendidas, e estender essa compreensão a outros contextos diferenciados, espacial e temporalmente, ou seja, do campo específico da História (SÃO PAULO, SE, 2012, p.33).

Os conteúdos estudados na escola só se tornam em saberes quando são resultados de um processo de aprendizagem significativa capaz de 
realizar a transposição didática dos conhecimentos escolares para a realidade do aluno. Todavia,

há um problema que se detecta com muita frequência. Quando se incorporam conhecimentos de ciências sociais às aulas, estes são apresentados como conhecimentos prontos, acabados, e em consequência os alunos não os relacionam exatamente com aquilo que é próprio de uma ciência. Acabam por considerar como científicas apenas as disciplinas das ciências naturais ou físicas e matemáticas, enquanto as sociais são percebidas como elementos de cultura, de curiosidade ou de mera repetição de datas comemorativas e acidentes geográficos.

Esta ausência de consideração do científico relacionado com o social faz com que a História, a Geografia e outras Ciências Sociais sejam vistas pelos alunos como disciplinas de memorização, mais ou menos interessantes, e que não admitem atividades discursivas, de indagação ou de resolução de problemas (PRATS, 2006, p.3).

A partir dessa concepção de saber, pode-se fazer o questionamento sobre a possibilidade de se falar em saber histórico em sala de aula a partir de uma metodologia de ensino tradicional da disciplina de História baseada numa educação bancária (utilizando-se do conceito de Paulo Freire), na qual o aluno é mero depósito de conteúdos prontos e acabados sobre datas, fatos e personagens que, muitas vezes, passadas as avaliações, são apagados da memória. Afinal, o conhecimento histórico só é possível de ser denominado de saber se for aprendido pelo estudante o seu papel enquanto agente da História, a importância da compreensão e reflexão crítica sobre o meio e a percepção da necessidade de uma intervenção consciente na realidade enquanto um cidadão ciente dos mecanismos de participação política em um Estado Democrático de Direito e a par dos problemas históricos nacionais. Nesse sentido, de acordo com Joaquín Prats,

é evidente que para avaliar se os conteúdos de História são úteis e necessários para os alunos e alunas do ensino regular, dever-se-ia 
PINTO, J. E. V. Saber Histórico e Desenvolvimento das Competências de Leitura e Escrita...

primeiramente definir se tais conteúdos respondem a alguma das suas necessidades educativas e se, de outro lado, estão ao alcance de suas capacidades. Do nosso ponto de vista, a disciplina responde plenamente às necessidades formativas dos alunos e constitui componente válido em um projeto de educação que não esteja baseado somente na acumulação de informação, mas que se volte ao desenvolvimento das capacidades das crianças e adolescentes (PRATS, 2006, p.4).

O saber histórico tem como pressuposto um modelo de ensino no qual o discente tenha um papel ativo na construção de sua aprendizagem, cabendo ao professor de História a função de intermediador entre os conteúdos e os alunos, adotando práticas pedagógicas que despertem o interesse dos discentes e conduzam ao estudo analítico, reflexivo e crítico do conhecimento histórico. Entre essas práticas, destacam-se o trabalho com a leitura de documentos e a produção de textos históricos, uma vez que

em uma cultura letrada como a nossa, a competência de ler e de escrever é parte integrante da vida das pessoas e está intimamente associada ao exercício da cidadania. As práticas de leitura e escrita, segundo as pesquisas que vêm sendo realizadas na área, têm impacto sobre o desenvolvimento cognitivo do indivíduo. Essas práticas possibilitam o desenvolvimento da consciência do mundo vivido (ler é registrar o mundo pela palavra, afirma Paulo Freire), propiciando aos sujeitos sociais a autonomia na aprendizagem e a contínua transformação, inclusive das relações pessoais e sociais.

Nesse sentido, os atos de leitura e de produção de textos ultrapassam os limites da escola, especialmente os da aprendizagem em língua materna, configurando-se como prérequisitos para todas as disciplinas escolares. A leitura e a produção de textos são atividades permanentes na escola, no trabalho, nas relações interpessoais e na vida (SÃO PAULO, SE, 2012, pp.15-16). 
Alguns docentes de História da rede estadual de educação básica do estado de São Paulo acreditam que a responsabilidade pela aprendizagem e pelo domínio das normas-padrão gramaticais da língua materna, da leitura e compreensão de textos e da redação de textos narrativos, descritivos e dissertativos por parte dos alunos na escola pública, seja tarefa dos professores de Língua Portuguesa. Por outro lado, outros questionam o fato de que, ao invés de se dedicarem exclusivamente aos conteúdos de História obrigatórios no currículo oficial, uma vez que dispõem apenas de quatro aulas semanais de 50 minutos no ensino fundamental e duas com a mesma duração de tempo na grade de aulas do ensino médio para tratarem de uma variada gama de conhecimentos históricos, têm que colaborar com os colegas de outra disciplina para a aquisição pelos estudantes das competências leitora e escritora e o alcance das metas de rendimentos em Língua Portuguesa pelas escolas nos exames do Sistema de Avaliação de Rendimento Escolar do Estado de São Paulo (SARESP), realizados pelas turmas de $9^{\circ}$ ano do ensino fundamental e $3^{\mathrm{a}}$ série do médio.

Entretanto, ao contrário da percepção de alguns professores de História, colaborar com a aquisição pelos estudantes das competências de leitura e escrita não se constitui em tarefa exclusiva apenas do docente de Língua Portuguesa e nem em ação colaborativa ou coleguismo para com os colegas de outra disciplina. Como se pensar no ensino de História sem que haja o domínio da leitura e da escrita por parte dos estudantes? É inconcebível a ideia de que o aluno seja sujeito ativo na aprendizagem dos diversos conteúdos de História com a adoção de uma didática tradicional baseada apenas na leitura em voz alta de textos para outros colegas, na cópia de resumos de textos do livro didático escritos pelo professor no quadro negro ou na lousa e em questionários do tipo pergunta e resposta que não exigem uma reflexão crítica em atividades e avaliações. Como afirma Fernand Braudel,

como pretende que o público escolar se interesse pela continuação da História? Deixa-se de mostrar o jogo para só se contar o fim da partida, que se discute a seu modo. Certo, não é assim que se deve proceder. A realidade histórica se estende pelo tempo, que é sua própria substância. Quando tiverdes de contar, e é preciso saber contar em nosso ofício, segui o declive do tempo, daí a impressão dessa mudança, que embaraça as linhas dos fatos, deforma os 
PINTO, J. E. V. Saber Histórico e Desenvolvimento das Competências de Leitura e Escrita...

seres, as sociedades, e marca o ritmo das gerações. Seria mister que pudéssemos falar horas a fio desse curso movediço das causas, restituir-lhes a fluidez e a vibração.

Mais um conselho, que ainda não será o último. Experimentai descrever a mentalidade de um contemporâneo. Automaticamente, povoareis o ambiente de sombras movediças em transformação, indícios que materializam a marcha do tempo (BRAUDEL, 1955, p.15).

$\mathrm{Na}$ realidade, as práticas pedagógicas tradicionais apenas reproduzem uma situação de comodismo ou, até mesmo, uma posição preconceituosa daqueles que as adotam no trabalho cotidiano em sala de aula em relação à capacidade dos alunos em adquirem o domínio necessário da leitura e escrita, ainda que seja em uma idade ou série e ano escolar fora da expectativa inicial. Desse modo,

possivelmente os alunos não estão aprendendo história e nem mesmo noções temporais. A história da cópia não ensina nem mesmo a ler e escrever. Só ensina a copiar e transcrever, o que não requisita que o aluno raciocine para além da estratégia de preenchimento de respostas, nem que se modifique pela linguagem oral ou escrita.

A concepção de leitor que essa situação indica é a de alguém que repete. Ou seja, o sentido está ali e o trabalho do aluno é falar o que já está no texto. Esse circuito de atividades sugere que, para os professores que compartilham dessa representação, faltam aos alunos condições não só de ler e escrever, como também de aprender História (ROCHA, 2010, p.135).

Tal didática apenas contribui para a reprodução entre os discentes de uma visão equivocada sobre a História, que consiste apenas em entendê-la como uma disciplina pautada na memorização de datas, acontecimentos e personagens sem qualquer significado para a realidade do aluno. Portanto, perde-se a possibilidade de se conscientizar o estudante sobre a importância da História para a sua formação intelectual e humana e o exercício de 
conhecimento do meio social e intervenção cidadã na transformação da realidade, pois

saber ler um jornal é uma habilidade "histórica", porque precisamos conhecer os modos como a manchete, a notícia, o lead, a reportagem etc. conectam-se e distribuem-se, estabelecendo ligações nada lineares, e também o caráter multimídia do jornal, que se estabelece entre os códigos utilizados (uma imagem pode se contrapor a uma manchete, por exemplo, criando, até mesmo, um efeito de ironia) (SÃO PAULO, SE, 2012, p.15).

Mas, afinal, o que se pode entender por competências leitora e escritora? Primeiramente, a palavra competência que aparece regularmente nos programas curriculares atuais diz respeito ao domínio do conjunto de conteúdos, saberes, metodologias e aprendizagens das disciplinas escolares que devem ser adquiridas durante o processo de formação intelectual e humana dos alunos para que eles possam raciocinar sobre as diversas situações impostas ao longo da vida pelo mundo que o cerca. Dessa maneira, terão condições para que possam tomar decisões de maneira consciente diante das tarefas e situações-problema colocadas pela existência. Para o Currículo do Estado de São Paulo: Ciências Humanas e suas tecnologias,

um currículo que promove competências tem o compromisso de articular as disciplinas e as atividades escolares com aquilo que se espera que os alunos aprendam ao longo dos anos. Logo, a atuação do professor, os conteúdos, as metodologias disciplinares e a aprendizagem requerida dos alunos são aspectos indissociáveis, que compõem um sistema ou rede cujas partes têm características e funções específicas que se complementam para formar um todo, sempre maior do que elas. Maior porque o currículo se compromete em formar crianças e jovens para que se tornem adultos preparados para exercer suas responsabilidades (trabalho, família, autonomia etc.) e para atuar em uma sociedade que depende deles (SÃO PAULO, SE, 2012, p.12). 
PINTO, J. E. V. Saber Histórico e Desenvolvimento das Competências de Leitura e Escrita...

As competências leitora e escritora referem-se ao domínio das técnicas e métodos de interpretação e produção de diversos tipos de documentos que possibilitem o acesso dos estudantes à produção cultural representativa de uma sociedade num determinado contexto. Com o aprendizado desse domínio possibilitado pelos saberes das disciplinas escolares, o aluno pode desenvolver a capacidade investigativa, coletar dados, decodificar informações, estimular o pensamento crítico, inserir-se na comunidade escrita, expressar as suas ideias e atuar conscientemente na sociedade. Logo, "é importante destacar que o domínio das linguagens representa um primordial elemento para a conquista da autonomia, a chave para o acesso a informações, permitindo a comunicação de ideias, a expressão de sentimentos e o diálogo, necessários à negociação dos significados e à aprendizagem continuada" (SÃO PAULO, SE, 2012, pp.17-18).

Contudo, o aprimoramento contínuo do trabalho pedagógico voltado para o desenvolvimento das competências leitora e escritora nos alunos depende também da capacitação permanente do professor. Em outras palavras, apesar das limitações de tempo e dinheiro ocasionadas pela realidade atual do exercício do magistério na educação básica do Brasil, o docente de História deve ser um leitor atento às produções historiográficas e pedagógicas clássicas e recentes como uma forma de se manter atualizado sobre as concepções da ciência histórica e os fundamentos teórico-metodológicos do ensino da disciplina. Dessa maneira, ele pode utilizar recursos didáticos e práticas pedagógicas renovados com o objetivo de tornar os conteúdos tradicionais repetidos há anos na sala de aula em instrumentos dinâmicos para a formação da memória e das identidades individuais e coletivas dos estudantes e, consequentemente, um aprendizado significativo do conhecimento histórico escolar. É recorrente que

a primeira reação de um profissional com muitas turmas e centenas de provas para corrigir é desanimar: "Eu não tenho tempo nem para ler o jornal, quanto mais tantos livros...". Calma! Não precisa imaginar que vai ler tudo em poucas semanas, mas precisa colocar a leitura como um tema central, especialmente para que você não ecoe a voz do desânimo dos alunos. O mais curioso é que nós, professores, diante de vários livros e textos, temos a mesma reação dos alunos: "ah, mais texto". Use então para você o discurso que faz em sala de aula para eles (KARNAL, 2016, p.133). 
O professor deve se esforçar para se tornar uma referência e um modelo de leitor a ser seguido para que o hábito de leitura seja uma rotina entre os seus alunos. Por outro lado, é esse hábito de leitura que proporciona a análise reflexiva e crítica dos documentos, adquirindo-se com o passar do tempo a capacidade de enxergá-los como um produto cultural resultante da mentalidade de uma sociedade num determinado período histórico. O incentivo à prática contínua do trabalho com a leitura e a interpretação de diversos tipos de documentos conduz à percepção por parte dos estudantes de que a produção historiográfica não é algo pronto e acabado, mas é o produto de um processo de seleção, relação e interpretação de dados e informações realizado pelo autor de um documento ou historiador, resultando numa narrativa histórica construída em torno de discursos e argumentos que buscam resgatar o passado, tendo-se como ponto de partida para o olhar sobre outros espaços e tempos históricos as demandas e expectativas do tempo presente. Portanto, de acordo com a Base Nacional Comum Curricular (BNCC),

a relação passado/presente não se processa de forma automática, pois exige o conhecimento de referências teóricas capazes de trazer inteligibilidade aos objetos históricos selecionados. Um objeto só se torna documento quando apropriado por um narrador que a ele confere sentido, tornando-o capaz de expressar a dinâmica da vida das sociedades. Portanto, o que nos interessa no conhecimento histórico é perceber a forma como os indivíduos construíram, com diferentes linguagens, suas narrações sobre o mundo em que viveram e vivem, suas instituições e organizações sociais. Nesse sentido, "o historiador não faz o documento falar: é o historiador quem fala e a explicitação de seus critérios e procedimentos é fundamental para definir o alcance de sua fala. Toda operação com documentos, portanto, é de natureza retórica". A História não emerge como um dado ou um acidente que tudo explica: ela é a correlação de forças, de enfrentamentos e da batalha para a produção de sentidos e significados, que são constantemente reinterpretados por diferentes grupos sociais e suas demandas - o que, consequentemente, suscita outras questões e discussões (BRASIL, MEC, 2017, p.395). 
PINTO, J. E. V. Saber Histórico e Desenvolvimento das Competências de Leitura e Escrita...

A partir do momento em que o professor enxerga no trabalho pedagógico com documentos um recurso fundamental para que o aluno possa desenvolver todo o seu potencial intelectual para a interpretação analítica e crítica de fontes históricas e a elaboração de produções textuais oriundas das compreensões e reflexões acerca das mais diversas temáticas relacionadas ao conhecimento histórico e à realidade discente, a disciplina não somente contribui para um salto qualitativo nas competências de leitura e escrita, mas, também, possibilita um aprendizado sobre a pluralidade de formas de se registrar e pensar a História em consonância com as dimensões espaciais e temporais de produção dos textos históricos. A respeito da linguagem presente nos documentos históricos, entendida como sistemas simbólicos utilizados pelo ser humano em diferentes contextos para representar uma determinada visão de si mesmo e da realidade, o Currículo do Estado de São Paulo: Ciências Humanas e suas tecnologias afirma que

pode-se definir linguagem como instrumentos de conhecimento e construção do mundo, formas de classificação socialmente determinadas. Esses sistemas simbólicos são, ao mesmo tempo, estruturados e estruturantes, uma vez que geram e são gerados no constante conflito entre os protagonistas sociais pela manutenção ou transformação de uma visão de mundo: o poder simbólico do fazer ver e fazer crer, do pensar, do sentir e do agir em determinado sentido.

Em síntese, as linguagens incorporam as produções sociais que se estruturam mediadas por códigos permanentes, passíveis de representação do pensamento humano e capazes de organizar uma visão de mundo mediada pela expressão, pela comunicação e pela informação (SÃO PAULO, SE, 2012, p.14).

O trabalho com a leitura de documentos e a produção de textos históricos possibilita a aquisição da capacidade de leitura crítica e escrita argumentativa a partir da identificação nos documentos das ideias, dos interesses, das disputas de poder e da ação de vários atores sociais em um determinado contexto histórico. Dessa maneira, o estudante pode perceber que os argumentos e a trama de acontecimentos e personagens presentes numa narrativa sobre um determinado fato histórico estão relacionados à 
formação, à visão de mundo e às demandas do segmento social, político, cultural e econômico do autor de um documento. Segundo Antônia Terra,

para perceber a presença do autor na obra, é preciso distanciar primeiramente a coisa representada (realidade) dos meios de representação (a obra - expressa em signos -, palavras, formas, cores...). No reconhecimento de que a obra não se confunde com as coisas da realidade é que se sente a presença do autor, isto é, daquele que exprime e representa, que fala, que constrói significados. O autor é um criador de imagens e do sistema de imagens da obra.

Por reconhecer a presença do autor na obra é que Bakhtin fala da necessidade das Ciências Humanas estudar o homem como sujeito que fala através de suas obras. Compreender e ver o autor significa ver e compreender, assim, uma outra consciência, isto é, um outro sujeito, aquele que expressa (TERRA, 2006, p.96).

Em outras palavras, a narrativa sobre o passado que chega até o presente não é um dado pronto, acabado e objetivo, mas uma construção fundamentada na argumentação e na seleção de acontecimentos e personagens capazes de constituírem uma certa visão sobre uma sociedade numa determinada época. Por esse motivo, no trabalho pedagógico com documentos históricos deve existir "uma busca de localização e de escuta das vozes, dos inúmeros sujeitos, embutidas nas obras, numa tentativa de aproximação com o enunciado, com as respostas, com as intencionalidades construídas pelo autor" (TERRA, 2006, p.100).

De modo similar, os questionamentos que os homens do tempo presente fazem sobre o passado e os vestígios deixados por ele estão relacionados à necessidade de compreensão do contexto atual e à projeção de ações de intervenção para a transformação da sociedade no futuro. Logo, é possível afirmar que a trama de personagens e acontecimentos e os argumentos presentes numa narrativa histórica, considerados irrefutáveis numa certa época, possam vir a se tornar passíveis de questionamentos em outro momento por causa das referências culturais, do protagonismo político dos diversos segmentos sociais e dos anseios da sociedade que são diversos. 
PINTO, J. E. V. Saber Histórico e Desenvolvimento das Competências de Leitura e Escrita...

Diante dessa constatação e levando-se em consideração os estudos da Psicologia sobre o nível de desenvolvimento cognitivo das crianças e adolescentes de acordo com cada etapa da vida escolar, a atividade didática de estudo comparativo de diversos documentos é importante para estimular os alunos a identificarem diferentes versões sobre um mesmo fato histórico, buscando-se compreender as razões para tais diversidades de enfoques analíticos e narrativos. Dessa maneira, os estudantes podem

reconhecer que as pessoas influem nas interpretações de um problema histórico. Segundo sua procedência, a época ou o lugar, a visão do fato é diferente. É necessário, inclusive, ter consciência de que existe uma relação estreita entre as descrições do passado e as fontes utilizadas para formular o relato. Os alunos e as alunas deveriam ser capazes de avaliar as interpretações históricas em função, inclusive, de sua distorção, assim como analisar os problemas que surgem quando se procura fazer uma História "objetiva".

Finalmente, os alunos e as alunas, ao final de seus estudos secundários, deveriam mostrar uma compreensão do fato de que os valores de sua época, de sua classe e nacionalidade, ou suas crenças, afetam os historiadores em seus juízos sobre o passado (PRATS, 2006, p.7).

Pode-se afirmar que o conhecimento histórico abordado nos diversos conteúdos do currículo da disciplina de História na educação básica está relacionado a um saber que valida socialmente as suas afirmações a partir da capacidade que tem de convencer à coletividade por meio de argumentos e de operações discursivas e linguísticas. Em suma, o saber histórico é um conhecimento que se constrói e se valida não por ser pronto, acabado e essencialmente objetivo numa perspectiva positivista. Pelo contrário, tem a sua validade baseada na capacidade do historiador em reunir indícios a partir das fontes históricas e de construir uma argumentação pautada no arcabouço teórico-metodológico da ciência histórica capaz de convencer os demais membros da comunidade acadêmica e da sociedade que sua análise do passado é plausível e pode os ajudar a compreenderem o tempo presente e 
servir de guia de ação para a mudança do meio social no futuro. Segundo Jacques Le Goff,

esta interação entre passado e presente é aquilo a que se chamou a função social do passado ou da História. Também Lucien Febvre [1949]: "A História recolhe sistematicamente, classificando e agrupando os fatos passados, em função das suas necessidades atuais. É em função da vida que ela interroga a morte. Organizar o passado em função do presente: assim se poderia definir a função social da História". Cada época fabrica mentalmente a sua representação do passado histórico (LE GOFF, 1990, p.26).

Em outras palavras, o conhecimento tem como pré-requisito para se tornar um saber histórico o fato de servir como fator de orientação temporal da vida prática presente, ou seja, quando é um instrumento capaz de criar uma consciência histórica nos indivíduos. Fazendo-se referência à definição feita pelo historiador alemão Jörn Rüsen (2001), é a consciência histórica que possibilitará aos indivíduos um processo cognitivo capaz de situá-los no fluxo do tempo. Devido a essa consciência, o ser humano usa a experiência do passado para orientar o seu agir no tempo presente e projeta uma nova realidade no futuro a partir do desenvolvimento de perspectivas de intervenção nela. Portanto, para Jörn Rüsen,

a consciência histórica é necessária a fim de que o agir (e o sofrer) humano não permaneça cego quando seu superávit intencional se realiza para além de suas condições e circunstâncias, por assim dizer quando avança na transformação do mundo pelo homem, e se dê na consciência de que esse avanço vai na direção correta. Sem essa determinação da direção, o potencial inovador das intenções do agir humano não poderia realizar-se; sem o direcionamento, esse potencial ficaria desnorteado e não poderia orientar as ações na forma de intenções - pois intenções nada mais são do que metas substantivas do ser humano. Essa teleologia é mediada pela consciência histórica por meio de seu recurso à experiência do tempo no passado do vetor intencional do agir, pelo qual a vida prática atual pode orientar-se, ao avançar no 
PINTO, J. E. V. Saber Histórico e Desenvolvimento das Competências de Leitura e Escrita...

mundo novo do futuro. Esse direcionamento é produzido pela consciência histórica mediante uma representação de continuidade entre as ações do passado e as do presente, de forma que se abram perspectivas de futuro (RÜSEN, 2001, p.81).

Se tal assertiva é verídica em relação ao saber histórico produzido no meio acadêmico e difundido no meio social em um determinado contexto, a mesma perspectiva pode ser aplicada ao saber trabalhado pelos docentes na educação básica, pois como é possível se conscientizar os estudantes sobre a importância do conhecimento abordado nos conteúdos da disciplina de História para a sua formação se não for por meio do trabalho pedagógico e da arguição do professor que os convençam de que a História é feita por todos os diversos segmentos sociais (nos quais se inserem os próprios discentes) sem distinção e que a leitura de documentos e a produção de textos históricos que tratam das ações desses grupos podem negar, menosprezar ou destacar o papel de cada um num dado momento por meio de narrativas baseadas em construções argumentativas e seleção de acontecimentos e personagens de acordo com os interesses em jogo e demandas sociais existentes na sociedade numa certa época? Essa reflexão remete-se à percepção da importância da introdução de um método de investigação histórica na educação básica a partir da heurística, ou seja, da busca e do levantamento de dados e informações presentes em documentos de toda espécie para que, numa etapa posterior, possa se desenvolver um trabalho de análise crítica dos autores, dos contextos de produção e das intenções dos discursos presentes nas fontes sobre narrativas e explicações de fatos e fenômenos históricos, prática denominada de hermenêutica. Isso contribui para que os alunos sejam sujeitos ativos no processo de ensino e aprendizagem de História e desenvolvam um posicionamento crítico em relação às informações e aos conhecimentos que recebem e compartilham cotidianamente. Assim, segundo Maria Auxiliadora Schmidt e Tânia Braga Garcia,

uma metodologia de ensino de História baseada na investigação tem como suporte uma concepção de ensino-aprendizagem onde o aluno tem um papel ativo e o professor a função de mediador. Assim, o seu fundamento básico é de que ela se realiza "mediante um processo de indagação, entendido não simplesmente como 
"fazer perguntas sobre a realidade", quer dizer, questioná-la e problematizá-la, mas também como busca de significados a qual exige do sujeito a realização de determinadas operações intelectuais para entender a experiência individual e coletiva”.

O segundo é o de que, além de poder propiciar respostas às questões da vida cotidiana, este tipo de ensino contribuiria para a concretização do trabalho histórico em sala de aula, ou seja, para a produção de um novo tipo de conhecimento o qual pode ser denominado saber histórico escolar, resultado de um determinado processo de didatização e axiologização do conhecimento. Podese indicar a presença da investigação como uma metodologia para o ensino de História possível e necessária em sala de aula, bem como a perspectiva da formação do professor de História como investigador social (SCHMIDT; GARCIA, 2003, pp.228-229).

Essas considerações das duas autoras mencionadas acima conduzem à crítica a uma dicotomia ou divisão social do trabalho existente entre o meio acadêmico, que seria o local exclusivo de investigação, pesquisa no sentido estrito e produção de conhecimento histórico, e a escola, que, por sua vez, teria como papel social apenas a formação intelectual e humana dos indivíduos, não sendo um lugar capaz de produzir saberes históricos compatíveis com o cotidiano da sala de aula e a realidade dos alunos, dos professores e demais agentes sociais inseridos na comunidade escolar e local. Disso decorre uma das perspectivas em voga até hoje em muitas instituições de ensino e que é característica de um modelo de ensino tradicional, isto é, a concepção de que cabe apenas à disciplina de História na educação básica reproduzir os conhecimentos gerados na universidade, consistindo as "pesquisas" escolares em meras cópias de textos retirados de livros ou páginas de pesquisa na internet. Tal postura não contribui para que a disciplina seja um importante instrumento para o aprimoramento do espírito investigativo, reflexivo e crítico que se espera de estudantes dotados de competências leitora e escritora. De acordo com Selva Guimarães Fonseca,

preocupados com a função social da História, vários historiadores fazem críticas a esta divisão do trabalho acadêmico, propondo o 
PINTO, J. E. V. Saber Histórico e Desenvolvimento das Competências de Leitura e Escrita...

redimensionamento da relação universidade e escola fundamental e de seus respectivos papéis. [...].

A preocupação das novas propostas curriculares caminha no sentido de mudar as práticas, o processo de ensino, o fazer pedagógico na sala de aula de tal forma que o acesso ao saber produzido se dê efetivamente por uma postura crítica ativa, aluno e professor na condição de sujeitos, contrastando com a condição de consumidores de informações, à qual estão submetidos. Esta postura é, de acordo com as propostas, condição para que eles construam conhecimento no processo de ensino-aprendizagem, entendido como processo de pesquisa e descoberta (FONSECA, 1993, p.92).

Trabalhar com a leitura e produção de textos na educação básica a partir de noções, métodos e temas próprios do conhecimento histórico não quer dizer que se queira transformar os alunos em historiadores capazes de escreverem artigos acadêmicos, monografias, dissertações ou teses. Pelo contrário, o objetivo do uso de tal atividade didática é propiciar as condições para que os estudantes possam ter autonomia no processo de ensino e aprendizagem em sua busca contínua pelo conhecimento, extrair e confrontar informações e ideias por meio da leitura criteriosa e interpretação de documentos, aprender a trabalhar com os diferentes padrões de medidas de tempo e a concepção de durações e ritmos temporais e situar ações de diferentes atores históricos no espaço e no tempo. Desse modo, segundo o Currículo do Estado de São Paulo: Ciências Humanas e suas tecnologias, a aquisição das competências leitora e escritora deixa de se pautar apenas numa visão tradicional e limitada que dá ênfase apenas ao domínio técnico de uso da língua portuguesa de acordo com os padrões estabelecidos pela normapadrão, priorizando-se um ensino que se preocupa, principalmente, com o

domínio da competência performativa: o saber usar a língua em situações subjetivas ou objetivas que exijam graus de distanciamento e de reflexão sobre contextos e estatutos de interlocutores, ou seja, a competência comunicativa vista pelo prisma da referência do valor social e simbólico da atividade linguística, no âmbito dos inúmeros discursos concorrentes. 
A utilização dessa variedade dá-se por meio de um exercício prático em situações de simulação escolar. A competência performativa exige mais do que uma atitude de reprodução de valores (SÃO PAULO, SE, 2012, p.15).

É importante se observar que as fontes a serem trabalhadas em sala de aula como recursos didáticos são diversas. Em consonância com a produção historiográfica acadêmica que, ao longo do século $\mathrm{XX}$, procurou incorporar novos sujeitos, novos objetos e novas abordagens, com destaque, a partir da década de 1960, para terceira geração da Escola dos Annales, também denominada de Nova História, não somente os textos oficiais escritos e impressos que relatam acontecimentos políticos, militares, jurídicos e diplomáticos ( certidões de cartórios, escrituras de compra e venda, atas do Parlamento, relatórios de órgãos públicos, legislações, etc.) são importantes recursos didáticos para o desenvolvimento das competências leitora e escritora por parte dos estudantes da educação básica, mas, também, o trabalho pedagógico com outros tipos de documentos como letras de músicas, gráficos, textos literários e jornalísticos, provérbios, diários, processos criminais e inquisitoriais, dentre outros, acrescentando-se a esses o uso de fontes orais como entrevistas, iconográficas, como gravuras, mapas, pinturas, esculturas, filmes, etc., e materiais, como utensílios e edificações, que se constituem em instrumentos fundamentais para se revelar os modos de viver, pensar e atuar dos diversos atores em diferentes espaços e tempos na História. Segundo a Base Nacional Comum Curricular (BNCC),

para se pensar o ensino de História, é fundamental considerar a utilização de diferentes fontes e tipos de documento (escritos, iconográficos, materiais, imateriais) capazes de facilitar a compreensão da relação tempo e espaço e das relações sociais que os geraram. Os registros e vestígios das mais variadas naturezas (mobiliário, instrumentos de trabalho, música, etc.) deixados pelos indivíduos carregam em si mesmos a experiência humana, as formas específicas de produção, consumo e circulação, tanto de objetos quanto de saberes. Nessa dimensão, o objeto histórico transforma-se em exercício, em laboratório da memória voltado para a produção de um saber próprio da História. 
PINTO, J. E. V. Saber Histórico e Desenvolvimento das Competências de Leitura e Escrita...

A utilização de objetos materiais pode auxiliar o professor e os alunos a colocar em questão o significado das coisas do mundo, estimulando a produção do conhecimento histórico em âmbito escolar. Por meio dessa prática, docentes e discentes poderão desempenhar o papel de agentes do processo de ensino e aprendizagem, assumindo, ambos, uma "atitude historiadora" diante dos conteúdos propostos (BRASIL, MEC, 2017, p.396).

Contudo, em decorrência da complexidade da discussão sobre o estudo da metodologia de ensino baseada no uso de cada um desses diferentes tipos de fontes, o objetivo deste artigo não é abordar todas as possíveis propostas pedagógicas relacionadas a cada uma delas em específico, mas analisar e discutir como a Secretaria de Educação do Estado de São Paulo propõe a utilização dos documentos e textos históricos como instrumentos essenciais para a aquisição das competências de leitura e escrita por parte dos alunos da educação básica. Para o Currículo do Estado de São Paulo: Ciências Humanas e suas tecnologias, espera-se que, a partir da leitura reflexiva e análise crítica de documentos e da prática da escrita de textos históricos, os alunos possam "desenvolver a capacidade de usar criticamente fontes de informação variadas, o que possibilitará o questionamento responsável da realidade, levando à formulação de problemas e ao encaminhamento de soluções adequadas e decididas coletivamente" (SÃO PAULO, SE, 2012, p.30).

Quando se pensa no trabalho pedagógico com a leitura de documentos e produção de textos históricos, a primeira preocupação que o professor deve ter é fazer um diagnóstico das condições socioculturais dos alunos, o que implica um estudo prévio sobre os hábitos de leitura de cada turma e a acessibilidade a fontes históricas por meio da identificação de possíveis recursos disponíveis para a busca e o levantamento de documentos, como, por exemplo, os livros disponíveis na sala de leitura da escola, os museus locais, as bibliotecas públicas, etc. Esse diagnóstico é importante porque o desenvolvimento cognitivo e a dinâmica de aprendizagem pode ser diferente entre crianças e adolescentes de um(a) mesmo(a) ano ou série, ainda que tenham a mesma faixa etária. Isso pode ser explicado porque as peculiaridades, vivências e experiências proporcionadas pelas condições socioeconômicas e pelo convívio das crianças e dos adolescentes nos ambientes familiar e social influenciam diretamente no processo de aprendizagem deles, implicando, 
portanto, em peculiaridades a serem levadas em consideração pelo professor no trabalho pedagógico com cada turma de alunos. Portanto, ensinar História na escola pública demanda que o professor saiba trabalhar com a diversidade e, por esse motivo, deve conhecer as condições de desenvolvimento cognitivo de seus alunos, planejando e organizando as atividades didáticas às particularidades de cada turma e escola.

Todavia, é necessário frisar novamente que o diagnóstico das condições socioculturais dos alunos antes do planejamento de uma aula que incorpore o trabalho com documentos e textos históricos como recurso didático para se facilitar e aprofundar o estudo dos diversos conteúdos da disciplina não implica numa posição de comodismo ou estigma do professor diante da percepção de possíveis condições de vulnerabilidade social dos estudantes. Pelo contrário, o professor deve encontrar meios de superar os obstáculos que possam se impor ao acesso à produção cultural na área de História por parte do alunos e, consequentemente, ao exercício de uma cidadania cultural, como, por exemplo, a inexistência de estímulos ao hábito de leitura no ambiente familiar e social frequentado pelos discentes e a dificuldade de acesso à leitura de textos. De acordo com Helenice Aparecida Bastos Rocha,

se o professor trabalha com turmas em que predominam condições de leitura e escrita precárias, presentes na maioria dos alunos de nossas escolas, seu problema passa a ser menos o da extensão do conteúdo a ensinar e mais o de assumir sua tarefa de professor de linguagem, inclusive a linguagem histórica. Esse problema, em sua magnitude, ainda persistirá algum tempo, independentemente de nossos desejos como professores letrados que somos. Assim, o aluno de nossa escola, em especial o da rede pública, poderá realizar sua formação histórica a partir de uma racionalidade mais ou menos letrada, oral ou escrita, com a contribuição dos professores de História (ROCHA, 2010, p.140).

Não pode também ser desconsiderada pelo professor de História a importância de se estabelecer uma comunicação permanente com o colega da disciplina de Língua Portuguesa, pois, além desses docentes poderem abordar simultaneamente a leitura de documentos e produção de textos de cunho 
PINTO, J. E. V. Saber Histórico e Desenvolvimento das Competências de Leitura e Escrita...

literário e histórico, a interdisciplinaridade tem como se fazer presente também por meio da troca de informações sobre os desafios encontrados e as conquistas obtidas pelos alunos individualmente e pelas turmas no desenvolvimento das competências leitora e escrita, utilizando-se para esse fim, sobretudo, a reunião coletiva semanal dos professores e da equipe gestora da escola, com duração de aproximadamente duas horas, denominada na rede estadual de educação básica de São Paulo como Atividades de Trabalho Pedagógico Coletivo (ATPC). Afinal, por causa do

caráter essencial das competências de leitura e de escrita para a aprendizagem dos conteúdos curriculares de todas as áreas e disciplinas, a responsabilidade por sua aprendizagem e avaliação cabe a todos os professores, que devem transformar seu trabalho em oportunidades nas quais os alunos possam aprender e consigam entender o uso da Língua Portuguesa e das outras linguagens e códigos que fazem parte da cultura, bem como das formas de comunicação em cada uma delas.

A centralidade das competências leitora e escritora, que a transforma em objetivo de todas as séries/anos e de todas as disciplinas, assinala para os gestores (a quem cabe a educação continuada dos professores na escola) a necessidade de criar oportunidades para que os docentes também desenvolvam essa competência (SÃO PAULO, SE, 2012, p.17).

Outro aspecto relevante a ser considerado diz respeito à necessidade de uma maior aproximação e comunicação entre as escolas das redes municipais, responsáveis, em geral, no estado de São Paulo, pela educação infantil e pelo ensino fundamental até o $5^{\circ}$ ano, e as unidades escolares da rede estadual de educação básica, que atualmente estão incumbidas do ensino fundamental a partir do $6^{\circ}$ ano e do médio. É recorrente o ingresso de alunos provenientes das escolas municipais na rede estadual de educação básica com graves problemas de alfabetização. Do mesmo modo, há obstáculos para o estabelecimento de uma maior cooperação entre as unidades escolares de ambas as redes no sentido de buscar alternativas para a solução dos déficits de aprendizagem dos estudantes ainda durante o processo de alfabetização. $\mathrm{Na}$ perspectiva de membros das equipes gestoras de escolas estaduais, tais 
obstáculos seriam decorrentes da dificuldade de obtenção de respaldo por parte das unidades escolares municipais, o que se explicaria pelas "questões corporativistas e de ego", pois os gestores dessas últimas demonstrariam resistência em aceitarem supostas ingerências das Diretorias Regionais de Ensino e de instituições de ensino estaduais em assuntos relacionados às escolas subordinadas às Secretarias Municipais de Educação.

Ademais, como já foi abordado anteriormente neste artigo, é importante que o professor compatibilize o trabalho pedagógico com documentos e textos históricos com os níveis de desenvolvimento cognitivo em que se encontram cada uma das turmas para as quais o docente ministra aulas. Afinal, não se pode esperar que, por exemplo, os estudantes do $6^{\circ}$ ano do ensino fundamental e da $3^{\text {a }}$ série do ensino médio tenham os mesmos níveis de compreensão e domínio de fenômenos de natureza histórica, do conceito e dos tipos de fontes históricas, das linguagens existentes nos documentos, da concepção de memória, das formas de notação e dos ritmos do tempo com as relações de curta, média e longa duração, etc.

Finalmente, é fundamental que, antes da utilização da leitura de documentos e produção de textos históricos como um recurso didático, o professor realize um planejamento das aulas, deixando claro como o trabalho pedagógico com os documentos pode ser um fator contribuinte para a efetiva aprendizagem por parte dos alunos dos conteúdos de História estabelecidos pelo currículo oficial. Para que isso ocorra efetivamente, é importante que o docente estabeleça o passo a passo das atividades relacionadas à leitura de documentos e produção de textos a serem desenvolvidas em sala de aula e os objetivos esperados com as práticas de seleção de documentos a serem estudados comparativamente, interpretação de fontes baseada em análises críticas e reflexivas e produção textual. Desse modo,

o debate e o diálogo, as perguntas que desmontam as frases feitas, a pesquisa, etc., tornam-se formas de auxiliar o aluno a construir um ponto de vista articulado sobre o documento. Nesse caso, o aluno deixaria de ser mero espectador ou reprodutor de saberes discutíveis para se apropriar do discurso, verificando a coerência de sua posição em face do grupo com quem partilha interesses. Dessa forma, além de se apropriar do discurso do outro, ele tem a possibilidade de divulgar suas ideias com objetividade e fluência perante outras ideias. Isso pressupõe a formação crítica, diante da 
PINTO, J. E. V. Saber Histórico e Desenvolvimento das Competências de Leitura e Escrita...

própria produção, e a necessidade pessoal de partilhar dos propósitos previstos em cada ato interlocutivo (SÃO PAULO, SE, 2012, p.17).

O Currículo Oficial do Estado de São Paulo estabelece que a atividade didática relacionada à prática de leitura e interpretação de documentos e produção textual histórica seja iniciada ainda no $1^{\circ}$ bimestre do $6^{\circ}$ ano do ensino fundamental, ou seja, assim que o aluno ingressa na rede estadual de educação básica, antes da abordagem de qualquer conteúdo relacionado a fatos históricos ocorridos em diferentes espaços e tempos, ele deve aprender os sistemas de notação do tempo, o conceito, as linguagens e a tipologia das fontes (documentos escritos, mapas, imagens, entrevistas), os suportes e instrumentos da escrita histórica, o modo como acontece a investigação histórica, a noção de memória e a sua importância para o conhecimento histórico, etc. $\mathrm{O}$ objetivo é que o estudante possa se familiarizar com conceitos básicos, métodos de pesquisa fundamentais e a linguagem da disciplina por meio do aprendizado prático sobre História. Isso possibilita um processo de ensino pautado na ideia do "aprender a aprender". Trata-se de um princípio educacional que defende a estratégia educativa de fornecer ao discente o instrumental conceitual, metodológico e linguístico para que possa buscar uma aprendizagem contínua de conhecimentos sobre um mundo complexo e em permanente transformação. Desse modo, o aluno adquire a autonomia necessária para buscar incessantemente, ao longo de toda a sua vida, aumentar os seus saberes e interagir com o mundo que o cerca por meio do exercício da atenção, da memória e do pensamento. Para o Currículo do Estado de São Paulo: Ciências Humanas e suas tecnologias, o "aprender a aprender" diz respeito a cinco competências que podem ser entendidas como desdobramentos das competências leitora e escritora:

*Dominar a norma-padrão da Língua Portuguesa e fazer uso das linguagens matemática, artística e científica. A constituição da competência de leitura e escrita é também o domínio das normas e dos códigos que tornam as linguagens instrumentos eficientes de registro e expressão que podem ser compartilhados. Ler e escrever, hoje, são competências fundamentais para qualquer disciplina ou profissão. Ler, entre outras coisas, é interpretar (atribuir sentido ou significado), e escrever, igualmente, é assumir 
uma autoria individual ou coletiva (tornar-se responsável por uma ação e suas consequências);

*Construir e aplicar conceitos das várias áreas do conhecimento para a compreensão de fenômenos naturais, de processos histórico-geográficos, da produção tecnológica e das manifestações artísticas. É o desenvolvimento da linguagem que possibilita o raciocínio hipotético-dedutivo, indispensável à compreensão de fenômenos. Ler, nesse sentido, é um modo de compreender, isto é, de assimilar experiências ou conteúdos disciplinares (e modos de sua produção); escrever é expressar sua construção ou reconstrução com sentido, aluno por aluno;

*Selecionar, organizar, relacionar, interpretar dados e informações representados de diferentes formas, para tomar decisões e enfrentar situações-problema. Ler implica também - além de empregar o raciocínio hipotético-dedutivo que possibilita a compreensão de fenômenos - antecipar, de forma comprometida, a ação para intervir no fenômeno e resolver os problemas decorrentes dele. Escrever, por sua vez, significa dominar os inúmeros formatos que a solução do problema comporta.

*Relacionar informações, representadas em diferentes formas, e conhecimentos disponíveis em situações concretas, para construir argumentação consistente. A leitura, nesse caso, sintetiza a capacidade de escutar, supor, informar-se, relacionar, comparar etc. A escrita permite dominar os códigos que expressam a defesa ou a reconstrução de argumentos - com liberdade, mas observando regras e assumindo responsabilidades;

* Recorrer aos conhecimentos desenvolvidos na escola para elaborar propostas de intervenção solidária na realidade, respeitando os valores humanos e considerando a diversidade sociocultural. Ler, nesse caso, além de implicar o descrever e o compreender, bem como o argumentar a respeito de um fenômeno, requer a antecipação de uma intervenção sobre ele, com a tomada de decisões a partir de uma escala de valores. Escrever é formular um plano para essa intervenção, formular hipóteses sobre os meios mais eficazes para garantir resultados a partir da escala de valores adotada (SÃO PAULO, SE, 2012, p.19). 
PINTO, J. E. V. Saber Histórico e Desenvolvimento das Competências de Leitura e Escrita...

Portanto, não há como se desvencilhar o princípio pedagógico do "aprender a aprender" de uma aprendizagem significativa de conceitos, saberes, metodologias e linguagens da disciplina de História que poderão ser mobilizados pelos estudantes com a finalidade de se refletir, compreender e intervir conscientemente na realidade em que se insere. No caso específico do $6^{\circ}$ ano do ensino fundamental, como sugere Helenice Aparecida Bastos Rocha (2010), a didática de leitura de documentos e produção de textos históricos deve partir da utilização de aspectos da realidade próxima dos alunos, como por exemplo, a história familiar e da comunidade local, como estratégia para a aquisição das habilidades de compreender e aplicar nos estudos históricos certos conceitos como fontes, tempo histórico, memória, etc., que parecem bem abstratos para se desenvolver, normalmente, com discentes que têm, em média, entre 11 e 12 anos por causa de seu nível de desenvolvimento cognitivo nesta faixa etária. Constam no Currículo do Estado de São Paulo: Ciências Humanas e suas tecnologias como habilidades a serem desenvolvidas pelos alunos do $6^{\circ}$ ano, no $1^{\circ}$ bimestre, durante o estudo dos conteúdos "Sistemas sociais e culturais de notação de tempo ao longo da História", "As linguagens das fontes históricas: Documentos escritos, mapas, imagens, entrevistas", "A vida na Pré-História e a escrita", "Os suportes e os instrumentos da escrita":

\footnotetext{
*Compreender fenômenos de natureza histórica;

*Reconhecer os acontecimentos históricos em sua temporalidade, estabelecendo relações de anterioridade e posterioridade;

*Reconhecer as diferentes formas histórico-sociais de marcação do tempo;

*Compreender que a construção do conhecimento histórico está vinculada a informações de natureza variada;

*Identificar a existência das diferentes linguagens das fontes históricas;

*Reconhecer a importância da escrita, identificando seus diferentes suportes ao longo da História;

*Elaborar o conceito de memória, reconhecendo sua importância para a construção do conhecimento histórico;

*Desenvolver o espírito investigativo e a autonomia ao buscar dados e informações (SÃO PAULO, SE, 2012, p.39).
} 
A didática de leitura de documentos e produção de textos históricos no $6^{\circ}$ ano pode incluir a visita a museus, arquivos, bibliotecas locais ou à sala de leitura da própria escola, a solicitação aos alunos para que elaborem desenhos ou escrevam redações ou narrativas em casa sobre as suas vidas desde o nascimento e determinados fatos históricos da comunidade local, o levantamento por eles de fontes como fotografias, objetos materiais e relatos orais de familiares ou pessoas da comunidade mais idosas sobre acontecimentos importantes da vida pessoal e coletiva, o estudo dessas mesmas fontes pelos demais colegas para lerem, interpretarem e escreverem a sua própria versão do passado e a confrontação estimulada pelo professor entre as diferentes redações elaboradas pelos estudantes a partir de fontes históricas iguais. De acordo com Helenice Aparecida Bastos Rocha,

preferencialmente, sobretudo nas séries em que o aluno começa a aprender História e sua característica descontextualizante, o professor pode elaborar atividades em que os alunos produzam materiais como desenhos e textos que funcionem como matériaprima para que esse circuito didático e contribuam com a pluralidade de formas de pensar a História, com ou sem escrita. Uma proposta como essa pode ser compreendida como reducionista. Mas não. É inspirada nas práticas do professor que acredita que seus alunos possam continuar a aprender a ler e escrever, mas principalmente podem conhecer e refletir com e a partir da História escolar (ROCHA, 2010, pp.139-140).

O professor pode também retribuir o empenho das turmas ao longo da atividade didática de uso de fontes e produção textual em História e colaborar para o despertar de uma consciência sobre a importância de se preservar a memória e se construir a identidade individual e coletiva dos estudantes, de suas famílias e da comunidade por meio da organização de exposições na escola com o resultado do levantamento, da coleta e da pesquisa de dados e informações e da elaboração de textos históricos pelos alunos. Afinal, para se utilizar com sucesso as fontes iconográficas, orais e materiais obtidas para o mencionado trabalho pedagógico são necessárias a participação ativa dos discentes e a colaboração de familiares e membros da 
PINTO, J. E. V. Saber Histórico e Desenvolvimento das Competências de Leitura e Escrita...

comunidade local. Dessa maneira, por meio dessas práticas escolares, pode-se perceber que

pertencer a uma comunidade, hoje, é também estar em contato com o mundo todo; a diversidade da ação humana está cada vez mais próxima da unidade para os fins solidários. A leitura e a escrita, por suas características formativas, informativas e comunicativas, apresentam-se como instrumentos valiosos para se alcançar esses fins. Na escola, o aluno deve compreender essa inter-relação como um meio de preservação da identidade de grupos sociais menos institucionalizados e como possibilidade do direito às representações em face de outros grupos que têm a seu favor as instituições que autorizam a autorizar (SÃO PAULO, SE, 2012, p.17).

Obviamente, essa ênfase na aproximação entre o trabalho com a leitura de documentos e a produção de textos nos diversos conteúdos de História estabelecidos pelo currículo oficial e o cotidiano e a realidade vividos pelos alunos pode e deve ser estendida também aos/às demais anos/séries da rede estadual de ensino de forma a proporcionar uma aprendizagem significativa dos fundamentos conceituais e metodológicos da disciplina ao longo de toda a vida escolar dos alunos. Contudo, o modo de se analisar mais abstrata e profundamente os ritmos e durações temporais, os processos de constituição de supostas "verdades" sobre o passado a partir de discursos, as tentativas de negação, minimização ou valorização de certos acontecimentos e atores históricos, etc. varia de acordo com cada etapa escolar do estudante, pois trata-se de um aprendizado contínuo sobre a interpretação e a produção do conhecimento histórico.

Nesse sentido, nos $6^{\circ}$ e $7^{\circ}$ anos do ensino fundamental, o Currículo Oficial do Estado de São Paulo estabelece o estímulo ao desenvolvimento de habilidades menos abstratas e complexas no que se refere ao desenvolvimento das competências leitora e escritora ao longo do estudo dos diversos conteúdos de História se comparadas às esperadas em outros(as) anos/séries, tais como ter noção clara das concepções de tempo, fonte e memória histórica, ter autonomia para procurar e coletar dados e informações históricas, saber localizar o local e o espaço histórico de elaboração das fontes, classificar cada documento de acordo com a tipologia das fontes, 
identificar o autor ou o segmento social responsável pela produção, analisar e perceber as ideias ou mensagens principais presentes nos documentos e desenvolver a capacidade de elaborar textos argumentativos a partir do estudo de variadas questões históricas. Entre as habilidades almejadas e citadas no currículo para os $6^{\circ}$ e $7^{\circ}$ anos e relacionadas ao desenvolvimento das competências leitora e escritora em História, podem-se observar:

*Compreender que a construção do conhecimento histórico está vinculada a informações de natureza variada $\left(6^{\circ}\right.$ ano);

*Identificar a existência de diferentes linguagens das fontes históricas $\left(6^{\circ}\right.$ ano);

*Reconhecer a importância da escrita, identificando seus elementos suportes ao longo da História $\left(6^{\circ}\right.$ ano);

*Elaborar o conceito de memória, reconhecendo sua importância para a construção do conhecimento histórico ( $6^{\circ}$ ano);

*Identificar nos códigos legais a presença e a preservação das desigualdades que caracterizam as sociedades ao longo da História ( $6^{\circ}$ ano);

*Desenvolver o espírito investigativo e a autonomia ao buscar fontes e informações ( $6^{\circ}$ ano);

*Identificar as características e os conceitos relacionados às várias temporalidades históricas ( $6^{\circ}$ ano);

*Estabelecer relações entre pontos de vista diversos sobre determinada questão histórica, visando à elaboração de argumentação consistente ( $6^{\circ}$ ano);

*Analisar textos históricos a partir das estratégias de estudo dirigido à leitura $\left(6^{\circ}\right.$ ano $)$;

* Reconhecer a importância das manifestações do pensamento para identificar os modos de vida das sociedades ao longo da História ( $6^{\circ}$ ano);

*Identificar fenômenos e fatos histórico-sociais em suas dimensões espaciais e temporais $\left(6^{\circ}\right.$ ano);

*Identificar, a partir de mapas e documentos iconográficos, as principais características das formações sociais ( $6^{\circ}$ ano);

* Classificar cronologicamente os principais períodos que dividem a história das sociedades ocidentais ( $7^{\circ}$ ano);

*Reconhecer a importância das fontes iconográficas para a construção do conhecimento histórico ( $7^{\circ}$ ano);

*Reconhecer, a partir de diferentes referências, a importância da cultura material como fonte histórica $\left(7^{\circ}\right.$ ano); 
PINTO, J. E. V. Saber Histórico e Desenvolvimento das Competências de Leitura e Escrita...

*Identificar, a partir de mapas e documentos escritos e iconográficos, as principais características das sociedades précolombianas (maias, astecas e incas);

*Reconhecer a importância do trabalho humano, identificando e interpretando registros sobre as formas de sua organização em diferentes contextos históricos (SÃO PAULO, SE, 2012, pp.3943, 46-47).

Além dessas habilidades, constam-se também nos $8^{\circ}$ e $9^{\circ}$ anos do ensino fundamental outras relacionadas às competências leitora e escritora em História no Currículo Oficial do Estado de São Paulo, que são justificadas pelo nível de desenvolvimento cognitivo compatível com a faixa etária média entre 13 e 14 anos dos alunos matriculados nessas duas etapas escolares. Entre as habilidades novas que aparecem, merecem destaques a comparação simultânea de dados e informações contidos em diversos documentos, a identificação da relação entre passado e presente por meio da presença de conceitos, pensamentos, ideologias e valores do passado em fontes históricas que repercutem nas sociedades contemporâneas, a capacidade de se perceber por meio do estudo dos documentos as noções de permanência e ruptura e perceber o papel importante dos diversos atores e segmentos sociais enquanto personagens da História. A relação de habilidades vinculada ao domínio da leitura e escrita na História para o $8^{\circ}$ e $9^{\circ}$ anos do ensino fundamental, que está presente no Currículo Oficial do Estado de São Paulo: Ciências Humanas e suas tecnologias, é a seguinte:

\footnotetext{
*Identificar, a partir de documentos, índios e negros como excluídos após a independência dos EUA ( $8^{\circ}$ ano);

*Identificar as influências do pensamento iluminista nos textos declaratórios da independência dos EUA ( $8^{\circ}$ ano);

* Reconhecer a importância de analisar textos de época para melhor compreensão de temas e conteúdos históricos ( $8^{\circ}$ ano);

*Identificar os principais valores propugnados pela Declaração dos Direitos do Homem e do Cidadão, de 1789, estabelecendo relações entre sua formulação e o contexto histórico em que foi produzida ( $8^{\circ}$ ano);

*Identificar as principais influências da Declaração dos Direitos do Homem e do Cidadão, de 1789, nas formas características das sociedades contemporâneas ( $8^{\circ}$ ano);
} 
*Reconhecer a importância da existência de um documento que estabeleça quais são os principais direitos humanos ( $8^{\circ}$ ano);

*Reconhecer a importância do uso das obras de arte para a construção do conhecimento histórico, especialmente para períodos anteriores à invenção da fotografia ( $8^{\circ}$ ano);

*Reconhecer, pelo estudo das obras de arte, a importância da presença dos viajantes estrangeiros para a "redescoberta do Brasil"' ( $8^{\circ}$ ano);

*Estabelecer relações passado-presente no estudo das permanências e rupturas que caracterizam a dinâmica do processo histórico ( $8^{\circ}$ ano);

*Identificar os principais conceitos do ideário dos movimentos revolucionários europeus do século XIX e suas influências nas posições político-partidárias da atualidade ( $8^{\circ}$ ano);

*Identificar, a partir de mapas, os principais movimentos históricos de ocupação territorial ( $8^{\circ}$ e $9^{\circ}$ anos);

*Identificar diferentes formas de representação de fatos econômicosociais expressos em diferentes linguagens ( $8^{\circ}$ e $9^{\circ}$ anos);

* Analisar, a partir de textos, os processos de transformação histórica, identificando suas principais características econômicas, políticas e sociais ( $8^{\circ}$ ano);

*Estabelecer relações a partir da seleção e organização de informações registradas em documentos de natureza variada $\left(8^{\circ} \mathrm{e}\right.$ $9^{\circ}$ anos);

*Analisar as justificativas ideológicas apresentadas pelas grandes potências para interferir nas várias regiões do planeta $\left(9^{\circ}\right.$ ano);

* Reconhecer a importância dos documentos visuais para a construção do conhecimento histórico ( $9^{\circ}$ ano);

*Reconhecer que o processo histórico não decorre apenas da ação dos chamados grandes personagens ( $9^{\circ}$ ano);

* Reconhecer, a partir de textos de natureza diversa, as principais características do período da Guerra Fria ( $9^{\circ}$ ano);

*Reconhecer a importância dos mapas para o estudo da História ( $9^{\circ}$ ano) (SÃO PAULO, SE, 2012, pp.48-54, 56-58).

Finalmente, durante o ensino médio, observa-se no currículo oficial uma proposta de trabalho didático mais detalhado e aprofundado com a presença de instrumentos, técnicas e métodos mais sofisticados para a análise de documentos e a construção de textos dissertativos em História, tais como o uso de conhecimentos de outras áreas do saber para o estudo de diversos tipos 
PINTO, J. E. V. Saber Histórico e Desenvolvimento das Competências de Leitura e Escrita...

de fontes (interdisciplinaridade), a crítica a determinados conceitos tradicionalmente utilizados na ciência histórica devido à perspectiva eurocêntrica presente neles, a compreensão do papel dos meios de comunicação para a construção e difusão nas sociedades de certas perspectivas sobre os fenômenos históricos, a análise comparativa e crítica de diversos modelos explicativos de fatos e processos históricos, o estudo da historicidade dos trabalhos historiográficos (a relação entre o trabalho do historiador, a sua biografia e formação e o seu pensamento), a discussão sobre o contexto de surgimento e a aplicabilidade de certos conceitos (direito, democracia, igualdade, liberdade, etc.) ao longo da História, entre outros. O Currículo Oficial do Estado de São Paulo: Ciências Humanas e suas tecnologias estabelece as seguintes habilidades relacionadas às competências leitora e escritora em História para as séries do ensino médio:

\footnotetext{
*Analisar processos histórico-sociais aplicando conhecimentos de várias áreas do saber ( $1^{\mathrm{a}}$ série $)$;

*Identificar características e conceitos relacionados às várias temporalidades históricas ( $1^{\text {a }}$ série);

* Reconhecer a importância de submeter à crítica o conceito de Pré-História, com base na crítica ao viés eurocêntrico e à delimitação pela ausência da escrita ( $1^{\mathrm{a}}$ série);

*Identificar as diferentes linguagens das fontes históricas, para a compreensão de fenômenos histórico-sociais ( $1^{\mathrm{a}}$ série);

*Reconhecer o papel dos diferentes meios de comunicação na construção do conhecimento histórico ( $1^{\mathrm{a}}$ série);

*Comparar diferentes explicações para fatos e processos históricosociais $\left(1^{\mathrm{a}}\right.$ série);

*Identificar as diversidades geocronológicas das produções culturais $\left(1^{\mathrm{a}}\right.$ série);

*Identificar, a partir de mapas, fenômenos e fatos históricosociais, considerando suas dimensões temporais e espaciais $\left(1^{\mathrm{a}}\right.$ série);

*Identificar a historicidade das interpretações históricas ( $1^{\mathrm{a}}$ série);

* Analisar, a partir de textos, os processos de transformação histórica, identificando suas principais características econômicas, políticas e sociais ( $1^{\mathrm{a}}$ série);

*Reconhecer fenômenos e fatos histórico-sociais a partir da análise comparada de mapas, considerando suas dimensões temporais e espaciais ( $1^{\mathrm{a}}$ série);
} 
*Comparar diferentes pontos de vista sobre situações de natureza histórico-cultural, identificando os pressupostos de cada interpretação e analisando a validade dos argumentos utilizados $\left(1^{\mathrm{a}}\right.$ e $2^{\mathrm{a}}$ séries $)$;

*Reconhecer a importância da cultura material para a construção do conhecimento histórico ( $1^{\mathrm{a}}$ série);

*Associar as manifestações culturais do presente aos processos históricos de sua constituição ( $2^{\mathrm{a}}$ série);

*Correlacionar textos analíticos e interpretativos sobre diferentes processos históricos-sociais ( $2^{\mathrm{a}}$ série);

* Relacionar as manifestações do pensamento e da criação artísticoliterária aos seus contextos históricos específicos ( $2^{\mathrm{a}}$ série);

*Associar as manifestações do ideário político contemporâneo às influências históricas ( $2^{\mathrm{a}}$ série);

*Identificar os principais valores propugnados pela Declaração dos Direitos do Homem e do Cidadão, de 1789, estabelecendo relações entre sua formulação e o contexto histórico em que foi produzida ( $2^{\mathrm{a}}$ série);

*Identificar as principais influências da Declaração dos Direitos do Homem e do Cidadão, de 1789, nas formas características das sociedades contemporâneas ( $2^{\mathrm{a}}$ série);

*Reconhecer a importância de um documento que estabeleça quais são os principais direitos humanos ( $2^{\mathrm{a}}$ série);

*Problematizar conceitos como direito, igualdade e liberdade no contexto da Revolução Francesa ( $2^{\mathrm{a}}$ série);

*Identificar os principais conceitos e influências do ideário dos movimentos revolucionários europeus dos séculos XVII e XVIII para a identificação das posições político-partidárias da atualidade ( $2^{\mathrm{a}}$ série);

*Identificar os principais conceitos do ideário dos movimentos revolucionários europeus do século XIX e suas influências nas posições político-partidárias da atualidade ( $2^{\mathrm{a}}$ série);

*Reconhecer a importância do uso de obras de arte para a construção do conhecimento histórico ( $2^{\mathrm{a}}$ série);

*Identificar, a partir de documentos, índios e negros como excluídos após a independência dos EUA ( $2^{\mathrm{a}}$ série);

* Analisar criticamente as justificativas ideológicas apresentadas pelas grandes potências para interferir nas várias regiões do planeta ( $3^{\mathrm{a}}$ série);

* Comparar pontos de vista expressos em diferentes fontes sobre um determinado aspecto da cultura ( $3^{\mathrm{a}}$ série); 
PINTO, J. E. V. Saber Histórico e Desenvolvimento das Competências de Leitura e Escrita...

\begin{abstract}
*Identificar diferentes formas de representação de fatos econômico-sociais expressos em diferentes linguagens ( $3^{a}$ série);

*Estabelecer relações entre as obras de arte e o contexto histórico de sua elaboração ( $3^{\mathrm{a}}$ série);

* Reconhecer, a partir de textos de natureza diversa, as principais características do período da Guerra Fria ( $3^{\mathrm{a}}$ série);

*Reconhecer que o processo histórico não decorre apenas da ação dos chamados grandes personagens ( $3^{\mathrm{a}}$ série);

*Identificar em diferentes documentos históricos os principais movimentos sociais brasileiros e seu papel na transformação da realidade ( $3^{\mathrm{a}}$ série);

*Identificar em diferentes documentos históricos os fundamentos da cidadania e da democracia em diversos momentos históricos $\left(3^{\mathrm{a}}\right.$ série);

*Identificar, a partir de documentos de natureza diversa, o processo de globalização da economia e seus principais efeitos sobre a sociedade brasileira ( $3^{\mathrm{a}}$ série) (SÃO PAULO, SE, 2012, pp.59-61, 63-73).
\end{abstract}

Como se pode notar, a relação de habilidades vinculadas à leitura de documentos e escrita de textos argumentativos em História desde o $6^{\circ}$ ano do ensino fundamental até à $3^{\mathrm{a}}$ série do ensino médio é extensa. Muitas são trabalhadas em anos/séries anteriores e se repetem até o final do ensino médio porque, além de serem pressupostos para a aquisição de outras requeridas em etapas posteriores da vida escolar, trata-se de uma estratégia didática encontrada pelo Currículo Oficial do Estado de São Paulo para o reforço e a consolidação das competências leitora e escritora almejadas para os alunos até a conclusão da educação básica. Essa estratégia se justifica pelas limitações impostas ao professor pelas dificuldades que os estudantes apresentam para atividades que envolvam a compreensão de documentos e a redação de textos, pois a disciplina de História é essencialmente baseada nas competências leitora e escritora capaz de possibilitá-los uma leitura do mundo, decodificando os contextos, desvendando os significados e o simbolismo das palavras, dos sons e das imagens e tomando uma posição crítica em relação à produção cultural criada pelos homens em diferentes temporalidades e espaços. 


\section{Considerações finais}

O trabalho pedagógico com a leitura de documentos e a produção de textos históricos facilita a aprendizagem significativa dos conteúdos curriculares porque cria as condições favoráveis para a transformação do conhecimento da ciência histórica em saber histórico escolar que pode ser compreendido, assimilado e praticado pelos estudantes. Isso demanda um planejamento pautado no levantamento e na seleção de fontes (heurística) e na organização da prática didática (iniciada pela hermenêutica ou prática de interpretação de fontes a partir da análise do autor, do contexto de produção, das correntes de pensamento às quais estão vinculadas o autor e dos fatos ou fenômenos, personagens e discursos/argumentos presentes nos documentos, culminando, a posteriori, no registro do conhecimento construído por meio de textos dissertativos) em consonância com os temas ou assuntos a serem ensinados e a realidade específica de cada grupo de alunos e da escola (o nível e o ritmo diferenciado de desenvolvimento cognitivo e aprendizado dos conteúdos, tempo letivo disponível para a disciplina, os recursos disponíveis para as atividades de leitura de documentos e produção de textos históricos, expectativas quanto ao domínio das competências leitora e escritora para cada ano/série, etc.). O objetivo é proporcionar o aprendizado efetivo dos conteúdos a partir da problematização dos temas/assuntos das aulas e do estímulo a um papel de sujeito ativo por parte dos discentes no processo de ensino e aprendizagem do conhecimento histórico por meio do estudo e da pesquisa com documentos históricos.

\section{Referências Bibliográficas}

ABUD, Kátia. Currículos de História e políticas públicas: os programas de História do Brasil na escola secundária. In: BITTENCOURT, Circe (org.). O saber histórico em sala de aula. 11 ed. São Paulo: Contexto, 2006, pp.28-41. 
PINTO, J. E. V. Saber Histórico e Desenvolvimento das Competências de Leitura e Escrita...

BLOCH, Marc Leopold Benjamin. Apologia da História, ou, O ofício do historiador. Trad. André Telles. Rio de Janeiro: Zahar, 2001.

BRASIL. Ministério da Educação. Secretaria de Educação Básica. Base Nacional Comum Curricular: educação é a base. Brasília: MEC/SEB, 2017.

BRAUDEL, Fernand. Pedagogia da História. Revista de História. São Paulo: Universidade de São Paulo, v. XI, n. 23, pp.3-21, jul.-set. 1955.

FONSECA, Selva Guimarães. Caminhos da História ensinada. Campinas: Papirus, 1993.

KARNAL, Leandro. A História Moderna e a sala de aula. In: (org.). História na sala de aula: conceitos práticas e propostas. 6 ed. São Paulo: Contexto, 2016, pp.127-142.

LE GOFF, Jacques. História e memória. Trad. Bernardo Leitão et al. Campinas: Editora da UNICAMP, 1990.

MACEDO, Elizabeth. Base Nacional Curricular Comum: a falsa oposição entre conhecimento para fazer algo e conhecimento em si. In: Educação em Revista. Belo Horizonte: UFMG, v. 32, n. 2, pp.45-67, abr./jun. 2016.

- Base Nacional Comum para currículos: direitos de aprendizagem e desenvolvimento para quem? In: Educação \& Sociedade. Campinas: CEDES, v. 36, n. 133, pp.891-908, out./dez. 2015.

- Base Nacional Curricular Comum: novas formas de sociabilidade produzindo sentidos para educação. In: Revista e-Curriculum. São Paulo: PUC/SP, v. 12, n. 3, pp.1530-1555, out./dez. 2014.

MATHIAS, Carlos Leonardo Kelmer. O ensino de História no Brasil: contextualização e abordagem historiográfica. In: História UNISINOS. São Leopoldo: UNISINOS, v.15, n.1, pp.40-49, jan.-abr. 2011.

PRATS, Joaquín. Ensinar História no contexto das Ciências Sociais: princípios básicos. Educar em Revista [online]. Trad. Elizabeth Moreira dos Santos Schmidt, Luciana Braga Garcia, Maria Auxiliadora Schmidt e Tânia Braga Garcia. 2006, n. spe, pp. 01-20. Disponível em: <http://dx.doi.org/10.1590/0104-4060.406.>

ROCHA, Helenice Aparecida Bastos. A escrita como condição para o ensino e a aprendizagem de História. Revista Brasileira de História. São Paulo: ANPUH, v. 30, n. 60 , pp.121-142, 2010.

RÜSEN, Jörn. Razão histórica: teoria da História/fundamentos da ciência histórica. Trad. Estevão de Rezende Martins. Brasília: Editora da Universidade de Brasília, 2001. 
SÃO PAULO. Secretaria de Educação. Currículo do Estado de São Paulo: Ciências Humanas e suas tecnologias. São Paulo: SE, 2012.

SCHMIDT, Maria Auxiliadora; GARCIA, Tânia Braga. O trabalho histórico em sala de aula. História \& Ensino. Londrina: Universidade Estadual de Londrina, v. 9, pp. 219-238, out. 2003.

TERRA, Antônia. História e dialogismo. In: BITTENCOURT, Circe (org.). O saber histórico em sala de aula. 11 ed. São Paulo: Contexto, 2006, pp.91-103.

RECEBIDO EM: 31/08/2018. APROVADO EM: 14/08/2019. 